\title{
Financial and Non-Financial Measures in Evaluating Performance: The Role of Strategic Intelligence in the Context of Commercial Banks in Kenya
}

\author{
Blandina Walowe Kori ${ }^{1}$, Stephen M. A. Muathe ${ }^{1}, \&$ Samuel Mwangi Maina ${ }^{1}$ \\ ${ }^{1}$ School of Business, Kenyatta University, P.O. Box 43844-00100, Nairobi, Kenya \\ Correspondence: Blandina Walowe Kori, School of Business, Kenyatta University, P.O. Box 43844-00100, \\ Nairobi, Kenya.
}

Received: August 24, 2020

Accepted: September 24, $2020 \quad$ Online Published: September 28, 2020

doi:10.5539/ibr.v13n10p130

URL: https://doi.org/10.5539/ibr.v13n10p130

\begin{abstract}
This study provides comprehensive discussion on role of strategic intelligence in commercial banks, in Kenyan context. The primary focus was to evaluate the performance of commercial banks using both financial and non-financial performance measurers. The financial measurers comprised return on equity (ROE), while non-financial measures were customer satisfaction, learning and growth, and internal processes. The study was anchored on resource-based view and balanced scorecard model. The target population comprised 40 commercial banks. Additionally, the sample size 181 was selected proportionately through stratified sampling procedure. Data collection instruments comprised closed and open -ended questionnaires and online review. The study used both primary and secondary data, where primary data was obtained from Kenya commercial banks head offices, while secondary data, for the year 2016 - 2018, was obtained from the annual reports of the central bank of Kenya. Data analysis was done using descriptive statistics and linear multiple regression analysis. Findings of the study indicate that strategic intelligence has a statistically significance on the performance of commercial banks in Kenya. Moreover, both financial and non-financial measures of performance are relevant in the banking sector and growth of Kenyan economy. The study recommends that commercial bank in Kenya should integrate their training focus and strategy implementation with investors interests based on balanced score card.
\end{abstract}

Keywords: strategic intelligence, performance, financial and non-financial measures, Kenya commercial bank

\section{Introduction}

Commercial banks in Kenya, as in the whole world play a very important role in transforming the economic framework of the country (UN, 2008). However, due to stiff competition in this industry it is necessary for the banks to apply different approaches to maintain sustainability (Zimmermann, 2019). One way of achieving such measures, therefore, is by supplementing financial dimensions with non-financial expertise (Eltinay, \& Masri, 2014). Accordingly, implementation of such strategies, helps managers to balance between short-term and long-term objectives, hence addressing a sustainable competitive scheme (Kaplan, 2009). To ascertain performance of commercial banks therefore, this study employed strategic intelligence as a yardstick. Strategic intelligence offers a special knowledge and a wider scope of sensitization to maneuver successfully in business arena. Strategic intelligence plays a vital role in aiding managers with valuable decision-making process (Khedr, Abdel-Fattah, \& Solayman, 2015).

Through strategic intelligence skills commercial bank managers mobilize savings for capital formation, provide savings services and investment capital successfully (Fuertes, Alfaro, Vargas, Gutierrez, Ternero \& Sabattin, 2020). Moreover, strategic intelligence facilitates health discussions between policy makers hence mediating sound decision making in the banking industry specifically on formulating successful monetary policies of a nation (Wilensky, 2015). In addition, strategic intelligence is a high contributor in innovation, improves technology through the synergy of artificial intelligence, business intelligence, competitive intelligence, and knowledge management (Kruger, 2010). Consequently, exploration of strategic intelligence in commercial banks is fundamental (Morton, 2016). It can help carb unexpected environmental challenges that can possibly hamper performance of Kenya commercial banks. 
Performance is understood as an achievement or an outcome of achieved goal or behaviour outcome (Gaudreau \& Braaten, 2016). Accordingly, performance is both behavioural and results or goal attainment oriented (Waheed, Abbas, \& Malik, 2018). Most of the time it happens, as an impact of repeated activity and it is linked to a successful process that is quantified in order to ascertain the level of attainment. Consequently, in a business setup, performance involves input and output of the resources whereby, whether the outcome is positive or negative, the recipient of the results makes the final judgment concerning the performance (Van, \& Shafagatova, 2016). Different concepts, therefore, links performance to the organisation achieved objectives (Sihag, \& Rijsdijk, 2019) In essence, the concept of performance robotically, involves an activity of benefit, value, or a worthwhile accomplishment. In other words, where there is efficiency, effectiveness, quality, or quantity, this is performance (OECD, 2015; Nenadal, 2016). In this study performance is linked to Kenya commercial banks on returns on equity (ROE), customer satisfaction, process and learning and growth.

Organisations use different models to measure performance such as statistical process control, workflow-based monitoring, or process performance measurement systems (Van \& Shafagatova, 2016). Some of the models used to measure performance are the Kaplan balanced scorecard, Keegan's performance matrix and or the Fitzgerald's framework of results and determinants (Neely, Mills, Platts, Richards, Gregory, Bourne, \& Kennerley, 2000; Van Looy \& Shafagatova, 2016). Keegan's performance matrix bears both internal and external aspects of business performance (Bititci, 2016). However, the model is criticized for lack of structure and that it is shallow lacking necessary details, thus fails to make links between different business dimensions more explicit (Striteska \& Spickova, 2012).

On other hand, Fitzgerald's matrix encompasses service quality, flexibility, resource utilisation and innovation, which are referred to as leading indicators. However, the indicators ignore customer resourcefulness in performance. It also comprises too many different tools, making it ambiguous, and hence fails to provide a clear process for developing performance model (Striteska \& Spickova, 2012; Bititci, 2016). The most common used measure is the Kaplan's balanced scorecard (BSC) (Olsen, 2011). Accordingly, Kaplan's viewpoints are that a good measurement for performance should capture not only financial data but also the nonfinancial information to adequately evaluate organisation performance (Kaplan, 2009).

Some organisation prefer using financial performance measures to present their business status since they give a short-term overview on the projected outcome in a short period time (Mashovic, 2018). Moreover, financial measurers provide adequate basis for understanding the financial position of a firm, hence regarded as best quantitative measures for evaluating business organisations' performance (Bogićević, Domanović, \& Krstić, 2016). The return on equity (ROE) is an important measurement of performance in this paper since it is an expression of a company's net income in a given period of time. The measure reflects the value of shareholders' returns and explains company's market value and effectiveness (Norman, 2017). Additionally, ROE provides the rate of return on their investment as opposed to return on assets (ROA) or return on capital employed (ROCE) and also it is comparable against cost of equity (COE) (Kabajeh, Al Nuaimat \& Dahmash, 2012; Pennacchi \& Santos, 2018). However, the weak side of short-range financial measurers is that, managers are likely to ignore or reject a positive NPV investment that have negative impact in the initial stages of evaluation, but which would have a high pay off in the later period (Mashovic, 2018).

On other hand, non-financial measures are incorporated in this paper since they play a big role during the formulation of long-term organisation strategies for customer satisfaction. Customer satisfaction is a strategic advantage and an inimitable firm resource (Mittal \& Frennea, 2010), while continuous learning is a source of knowledge acquisition, distribution, information interpretation and organisation memory (Namada, 2018). On other hand review of internal processes provide continual evidence about the validity of the assumed firm's strategies (Kaplan \& Norton, 2005). In this case therefore, non-financial measures are valuable measures since they determine the future of the firm (Looy \& Shafagatova, 2016). In other words, commercial banks in Kenya can benefit a lot from understanding and using their lead indicator strength found in nonfinancial metrics (OConnell, \& OSullivan, 2016). Intelligent integration of the financial and nonfinancial measurer is considered as a way to improve the performance of commercial banks in Kenya whose performance deteriorated due to closure of some banks between 2016 and 2018 (CBK, 2018). Accordingly, the average net interest margin declined from $8.96 \%$ in 2016, 8.4\% 2017 and 7.9\% 2018. This was caused by the drop-in capital adequacy and fall in asset quality in the year 2017 (CBK, 2018). The drop-in capital for one commercial bank affects the whole economic standing of a nation (Ekinci \& Poyraz, 2019). This implies therefore that, commercial banks in Kenya must intelligently focus on improving state of the economy without fail.

Strategic intelligence is the provision of information about targets of concern, action taking and intelligently focusing on better future (Marín, 2015; Bang, 2017). According to Fernández-Villacañas Marín (2015) strategic 
intelligence is the basis of organisational intelligence, thus it has a close relationship with the dynamism of the business organizations such as banking industry. Levine, Bernard, and Nagel (2017) states that strategic intelligence is an administrative prototype and that it provides different instructive optics on how management works in general. Thus, failure to address intelligence agencies as of part organisation's needs, leads to operations lacuna both in competitive business arena and organisation performance. Though, it appears as an abstract phenomenon in minds of the top-level managers, it is a cognitive map of a social reality which enacts inter-subjectively, and stalwartly used as source of expedient business information (Abbaspour, Amirkhani, Ezzat \& Hozori 2018).

Through strategic intelligence managers formulates viable strategies, policies, business strategic plans and operations (Kruger, 2010). The managers intelligently generate data pool within organisations, and skillfully store, retrieve, and evaluate relevant and reliable data for various use (Kumaresan \& Liberona, 2013). Another aspect of strategic intelligence is the reporting procedure and the integration of the data for sound decision making (Twum \& Amoako, 2014). Further, strategic intelligence facilitates accurate forecasting of important events, correctly relate the uncertainties essential in such forecasts, while effectively sharing those probabilistic predictions to stakeholders (Mandel, \& Barnes, 2014). Intelligence strategist are also analysts since, they deal with highly ambiguous situation on the basses of processed information, but also scans and illuminate the unknown and less significant (Xu \& Kaye, 2007).

Accordingly, there are reasons why organisations choose to increase intelligence; one being for need of collective assemblage of value-added benefits derived from organisation's intangible assets (Liebowitz, 2006). This may involve proper searching for, selecting, processing interpreting the organisational intelligence, and finally come up with sound decision-making (Dhami, Mandel, Mellers \& Tetlock, 2015). In banking industry high rate of competition is evident and pose threats to growth and sustainability, thus proper environmental scanning and sound decision making is absolutely necessary (Ahmed \& Runggcharoenkitkul, 2014). Commercial banks need strategic intelligence for accurate implementation of set objectives and goals, since it provides good data governance policy to top-level management team. On other hand the operation level may need intelligence in order to properly leverage all that it entails for business success and transform data into actionable insights and decision making (Silas, 2013). Knowledge gained from both levels, therefore, helps the commercial banks to properly analyse its economic status and position, provide commercial and economic security and finally invest in compliance and monitoring efforts.

\section{Review of Literature}

\subsection{Theoretical Review}

This study was anchored on the Penrose's' (1959) theory of resources-based view (RBV) for organisation growth (Kor, \& Mahoney, 2004). Accordingly, Penrose view was that resources are evolutionary and cumulative process of learning, such that the more the firm advances in learning, the more the growth and expansion due to its supernormal returns (Pitelis, 2004). This implies that resources possessed in a firm are the bases for the firm performance and its sustainability (Andersén, 2011). Moreover, they are a source of competitive edge and excellent positioning of the firm (Das \& Teng, 2000). RBV is mainly associated with firm's internal processes heterogeneity schemes for competitiveness (Almarri \& Gardiner, 2014). Barney (2001) suggests that an apt RBV should possess attributes such as viability, rare, inimitable, and non-substitutable (VRIN). The main aspects that Barney brings forth in RBV attributes is that resources should be profitable hence they should take a form of economic regard and an expected future income. This phenomenon has been tested in different forms of studies, both in meta-analysis and empirical scenario such as in banking sector (Timothy, 2010; Nason, \& Wiklund 2018). However, the theory has been criticized in that RBV fails to consider factors surrounding the resource, in a way that the concept assumes that resources simply exists without keenly trying to find out how key capabilities are acquired or developed (Essays, 2018). Accordingly, the market is continuously changing, hence the managers keep on reconfiguring, integrating, and building the internal environment, such that the RBV cannot stand alone, hence it is extended to dynamic capabilities theory (Gomes \& Romão, 2013).

The concept of dynamic capabilities (DC) is regarded as an aptitude of the organisation to practice integration (Teece, Pisano \& Shuen, 1997). Further, Teece et al., (1997) uphold that dynamic capabilities are imperative in firm growth because they build and reconfigure internal and external competences. Accordingly, the authors espouse that dynamic capabilities are competences that can be distinguished from operational proficiencies in that, they provide the firms with capacity to create, extend and or modify its resources (Teece, Pisano \& Shuen, 1997). The theory assumes that core competencies should be used to modify short-term competitive positions and enable the firm to build longer-term competitive advantage (Faiz, 2007). This is typically the role of 
financial and nonfinancial measures. Financial measurers show a short-term performance picture to its shareholders while internal processes activate managers initiative for competitions, and customer perspective sharpens the mangers focus on the most important people (the customer), who enhance learning and growth. The energy of dynamic capabilities spars across the business because of the fuel that comes from organisation strategic intelligence. Strategic intelligence develops context, knowledge and understanding of the changing environment.

The concept of strategic intelligence was pioneered by the classical scholars in the United States in 1947 (2010). Strategic intelligence concept evolution took four phases starting from second world war time, second phase concentrated on the analysis which assisted policy makers with facts hence making informed decisions, third phase improved the previous two phase's deficiency through scientific advances and development of technologies and the fourth phase started when terror globally began to shake the world from 1997 (Poteat, 2011). Theory is classified in three categories including strategic intelligence, tactical intelligence and operational intelligence, and the main focus is on broad issues which impact strategy such as national economics or global economics among others (Westerfield, 2001).

Theory associated with strategic intelligence are the theories of power which Max Weber defines as the ability to achieve goals, control activities, events, or resources, to make things happen despite the obstacles, resistance, or opposition. Accordingly, Weber maintains that power is derived from three domains: traditional, charismatic, and legal or rational (Gingrich, 2007). This study is anchored on charismatic authority domain which according to Weber the person with such ability can easily influence directions. Moreover, where power flows freely, from a social system's hub, has potential to coordinate human activities and resources to achieve the desired goals (Turner, 2005). This notion is found in military setting. However, though strategic intelligence concept begun as a "military" strategy, it has been adapted profoundly in business scenery and domains, such that it equips strategists with intrinsic power to collect, process, analyze and disseminate intelligence and solve related business problems (Străin, 2013). Consequently, it is meant to reduce the levels of uncertainty by inaugural business opportunities that could possibly lead to profits maximization. This, therefore, affirms that strategic intelligence involves power and its heuristic value before entity positioning, exploiting and finally bringing it to shape and competitiveness (Gill, 2010; Marín, 2015).

Some objectives of strategic intelligence are to identify points of opportunities, attainment of comparative advantage, and maximize performance of individual organisations (Treverton, Jones, Boraz \& Lipscy, 2006). In many scenarios, strategic intelligence is used to create business grand strategy (Heidenrich, 2007) This implies that it enhances planning, it is also a market intelligence because it is a systematic and continuous intelligence process and it is customers perspective. This then informs that strategic intelligence concept is a primacy of value creation for a stakeholder. Moreover, strategic intelligence is described as a strategic policy making tool, actions based, process, or information protector and a participatory decision-making instrument (Clar \& Acheson, 2008). The strength of application of the strategic making tool is its inclusivity of all stakeholders (Clar \& Acheson, 2008). Freeman, author of stakeholder theory, between 1980 and 1983, affirms that there are high benefits to firms that give priority to its stakeholders needs, since it is through stakeholders that they maximize profits hence gaining high returns on equity (ROE) (Freeman, Harrison, Parmar, Wicks \& Colle, 2010; Masharsky, 2014; Abdallah, 2015).

Strategic intelligence is associated with surveillance activities for security purposes; hence the executions are confidentially conducted (Gill, 2010). Intelligence, therefore, is knowledge management. Accordingly, AlSuwaidan and Zemirli (2015) affirms that knowledge management depicts an intelligent behaviour and adroit in competition. Another concept associated with strategic intelligence is the Kaplan's balanced scorecard which dates back in 1950s (Kaplan, 2009). Balanced scorecard model is both a financial and non-financial prototypical idea. According to Alnoukari, Razouk, \& Hanano (2016) management are more interested on financial measurements and that they are used to evaluate company position in the market. The main idea for Kaplans model was basically to address both short and long-term performance strategies of a business. Coalescing strategic intelligence with balanced scorecard, therefore, provides a business with an information hub. Furthermore, an implementation of the same defines a strategic map to the firm and an environmental scanning avenue. For example, business processes outputs are associated with business objectives, aligned with organization's strategy and enhanced by learning and growth measurements. Hence combine with customer perspective measurements, this portrays a company's image (Alnoukari, Razouk, \& Hanano, 2016).

Malgwi and Dahiru (2014) argue that the more an organisation is able to answer questions on how they can attract and retain more investors, the more the chances of superior performance. Balanced scorecard is commercial but also customer perspective and learning and growth, which are the non-financial measurers of 
this study. As such, strategic intelligence is a foresight, strategic warning, learning process, creative making tacit knowledge explicitly, evaluating technology, facilitating process, and linking them with decision-making (Kuosa, 2014; Schmidt, 2015).

\subsection{Empirical Review}

The banking sector in Kenya comprise of the Central Bank of Kenya (CBK), commercial banks, and other banking institutions and foreign exchange bureaus. The sector operates under the guidelines of the Kenyan Constitution Act no. 488 for banking, and the Central Bank of Act 491 (Momanyi, 2018). The total number of operating commercial banks in Kenya stands at fourty (40), excluding the banks under statutory management and on receivership, between 2015 -2018 (CBK, 2018). Based on the data from 2016, records indicated commercial banks in Kenya registered higher profitability by $24.6 \%$ on average. This was the year when a law on capping interest rate was passed (Chironga, Cunhaand \& DeGrandis, 2018).

However, despite the positive indicators, commercial banks average net interest margin declined from $8.96 \%$ in 2016, 8.4\% 2017 and 7.9\% 2018. This was caused by the drop-in capital adequacy and fall in asset quality in the year 2017 (CBK, 2018). The drop-in capital for one commercial bank affects the whole economic standing of a nation (Ekinci \& Poyraz, 2019). This, therefore, disrupts the current country's vision 2030 which aim to create a globally competitive and prosperous country with a high quality of life.

Studies indicated that strategic intelligence practices can lead to greater profitability in Kenyan banking industry (Mugo, Wanjau, \& Ayodo, 2012). Strategic intelligence is a fundamental information provider, and best tool for decision making (Svensson, Pellissier, R., \& Kruger, 2011). It is formed from a combined synergy of business intelligence, competitive intelligence, and knowledge management. The concept can be amalgamated with Kenyan vision 2030 which aims to transform the country to a middle-income and provide its citizens with high quality of life (Mwenzwa \& Misati, 2014). Accordingly, the vison 2030 economic pillar is fused with the Third Medium Term Plan (MTP-III) (2018-2022) The Big Four" agenda on the focus to make Kenyan banking industry a strong global competitive financial sector (Team, Perrault, Kilo, \& Hettinger, 2013; Odhiambo, 2013;). This also would have a positive effect on the Kenyan economy and life standard of the Kenyan citizen (Ngugi, Gakure, \& Mugo, 2012).

A study by Kinyua, Muathe and Kilika (2015) focused on knowledge management and performance, while Musau, Muathe and Mwangi (2018) focused on financial inclusion and commercial banks stability. On other hand Mutuku, Muathe and James (2019) based their focus on e-commerce capabilities and performance of commercial banks in Kenya. However, these studies ignored the quintessence of strategic intelligence in commercial banks performance. Moreover, Musau et al (2018) and Mutuku et al. (2019), used secondary data which is subject to generalization, deleted data such as the confounding variables or outdated information (Cheng \& Phillips, 2014). On other hand Kinyua et al. (2015) measured performance using non-financial data and ignored the financial measures. However, a good measure of performance should contain both financial and non-financial measures (Kaplan 2005). The current study used both primary and secondary data and measured the performance of commercial banks using both financial and non-financial measurements.

Due to the argent need for improvement on performance of banking sector, and competitive strategies to boost the Kenyan economy (Ngugi, Gakure \& Mugo 2012; CBK, 2017) therefore, the current research was necessary. The study investigated the role of strategic intelligence in the context of commercial banks in Kenya. The study, thus, tested the following hypotheses:

$\mathrm{HO}_{1}$ : Strategic Intelligence has no significance effect on financial performance of commercial banks in Kenya

$\mathrm{HO}_{2}$ : Strategic Intelligence has no significance effect on non-financial Performance of commercial banks in Kenya.

\section{Research Methodology}

This study adopted two designs: a cross-sectional descriptive survey and explanatory research design. According to Morse and Niehaus (2009) the use of two or more methods in a study is referred to as a multimethod approach. Multiple methods provide a wider spectrum for more informed data interpretation and conclusion as compared to a single research design (Johnson, Onwuegbuzie \& Turner, 2007). The method is integrative, hence provides strategies to link between qualitative and quantitative projects, thus forming components of one research programme (Seawright, 2016). Consequently, the study used both cross sectional descriptive survey and exploratory research design. Descriptive design was appropriate because it generates both qualitative and quantitative data through research questions (Koh \& Owen, 2000), while explanatory research design identifies 
the cause and effect, hence linking between the independent and dependent variables that pertain the research problem.

The target population for this study comprised 40 commercial banks in Kenya categorized as large, medium, and small size based on the market share. Accordingly, this was the entire population of the banks in Kenya as at $31^{\text {st }}$ December 2018 (CBK, 2018). The sample size was 181respondents obtained through proportional sampling technique, using a ratio of 0.15 at 95 percent level of certainty from a Krejcie and Morgan's table for determining sample size (Krejcie \& Morgan, 1970). The unit of analysis, from which the census was conducted was 40 commercial banks, while the unit of observation were the managerial team in various functional areas from each bank. The sampling procedure followed the following steps: First the key functional areas relevant to this study in each bank, such as finance department, strategic management department, marketing and communication department as well as the information technology and operations departments were sampled.

Secondly, proportionate stratified random sampling technique was conducted to get the required sample size from each department to ensure representativeness. Simple random sampling technique was used to ensure that every member of the sampled department had a known and equal chance of being selected (West, 2016). The management team from each bank provided the sample size. Thus, the large banks provided a total of 41 respondents, medium banks provided 45 respondents while small banks provided 95, forming a total of 181 respondent. Data collection instruments were questionnaires for empirical data and document review source for secondary data.

Empirical model for performance variable comprised both financial and non-financial measurers in separate models. The financial measures were Return on Equity (ROE), while non-financial measures were abbreviated as (NFP). which was an aggregated mean of the Likert scale constructs. The models indicated below were used.

$$
\begin{array}{r}
\mathrm{ROE}=\boldsymbol{\beta}_{0}+\boldsymbol{\beta}_{1} \mathrm{BI}+\boldsymbol{\beta}_{2} \mathrm{CI}+\boldsymbol{\beta}_{3} \mathrm{KM}_{+} \varepsilon \ldots \ldots \ldots \ldots \ldots \ldots \ldots \ldots \ldots \ldots \ldots \ldots \ldots \ldots \ldots \ldots \ldots \ldots \ldots \ldots \ldots \ldots \ldots \ldots \ldots \ldots \ldots \ldots \ldots \ldots \ldots \ldots \ldots
\end{array}
$$

Where: -

$$
\begin{aligned}
& \text { ROE }=\text { Financial Performance } \\
& \text { NFP = Non-Financial Performance } \\
& \boldsymbol{\beta}_{\mathbf{0}}, \boldsymbol{\beta}_{\mathbf{1}}, \boldsymbol{\beta}_{\mathbf{2}}, \boldsymbol{\beta}_{\mathbf{3}} \text { beta coefficient } \\
& \mathbf{B I}=\text { Business Intelligence } \\
& \mathbf{C I}=\text { Competitive Intelligence } \\
& \mathbf{K M}=\text { Knowledge management } \\
& \boldsymbol{\varepsilon}=\text { Error Term }
\end{aligned}
$$

\section{Findings and Discussion}

The presentation of the results includes the descriptive statistics, model summary and multiple regression analysis. Table1 presents the information on non-financial measures provided by respondents through a five-point Likert scale to measure the extent agreement with the suggested statements.

Table 1. Non-Financial Performance Measures (NFP)

\begin{tabular}{lll}
\hline Descriptions & $\begin{array}{l}\text { Mea } \\
\text { n }\end{array}$ & $\begin{array}{l}\text { Standard } \\
\text { Deviation }\end{array}$ \\
\hline Assess customer satisfaction and customer complaints. & 3.22 & 1.46 \\
Enables banks to assess sales of new products & 3.24 & 1.43 \\
Enables banks to observe services levels and delivery. & 3.27 & 1.47 \\
Enables banks to observe customer lost or won & 3.28 & 1.44 \\
Enables banks to assess brand awareness, & 3.28 & 1.46 \\
Helps banks to observe employee empowerment and motivation through training and & 3.56 & 1.37 \\
development. & 3.59 & 1.46 \\
Helps banks to observe information systems capabilities. & 3.76 & 1.50 \\
Helps banks to produce goods/services in the most effective and efficiency way. & 3.80 & 1.50 \\
Captures new markets with speed as they arise. & 3.81 & 1.51 \\
Helps banks to observe employee capabilities for more innovations. & 3.83 & 1.56 \\
Enhance innovation & $\mathbf{3 . 5 1}$ & $\mathbf{1 . 4 7}$ \\
\hline Aggregate Mean Score and Standard Deviation & & \\
\hline
\end{tabular}


From table 1 therefore, results indicate that, on average non-financial measures contributed to the performance of Kenya commercial banks to a moderate extent with mean score of 3.51 and standard deviation of 1.47. These results were in line with the findings of Lucianetti, Battista \& Koufteros (2019). In essence, Non-financial measures help to improve and translate the organisational strategy as such enhancing internal communication among employees. Non-financial measures are customer cautious, hence provides satisfaction and a keenly handles customer complaints as they arise. This helps the banks to observe losing customer and retain the customer won. Moreover, findings indicate that through non-financial metrics banks can easily assess sales of new products, observe services levels and deliveries, observe efficiency and effectiveness and vigorously work on innovation and inventions. This lessens commercial banks risk and efforts on implementing strategies for new market entry, penetration, development, and diversification as coined by Ansoff in 1957 Meldrum, and McDonald (1995).

The financial performance of commercial banks was also captured through return on equity (ROE). Return on equity ratio measures the amount of a corporation's income returned as shareholder's equity; thus, it shows efficiency, profitability and how effective the management uses investors' money (Kijewska, 2016). ROE is a short-run predictor of both bank standalone ratting (BSRs) and systematic risk in time of crisis (Moussu, Petit-Romec, 2017). It was a relevant measure for performance in Kenya commercial banks, since the banking sector has a government deposit insurance fund that covers depositors against losses (Kenya Deposit Insurance Act, 2012). Moreover, stock market investors focus on ROE which is normally reflected on the book value and also a center of attraction to investors (Pennacchi \& Santos, 2018).

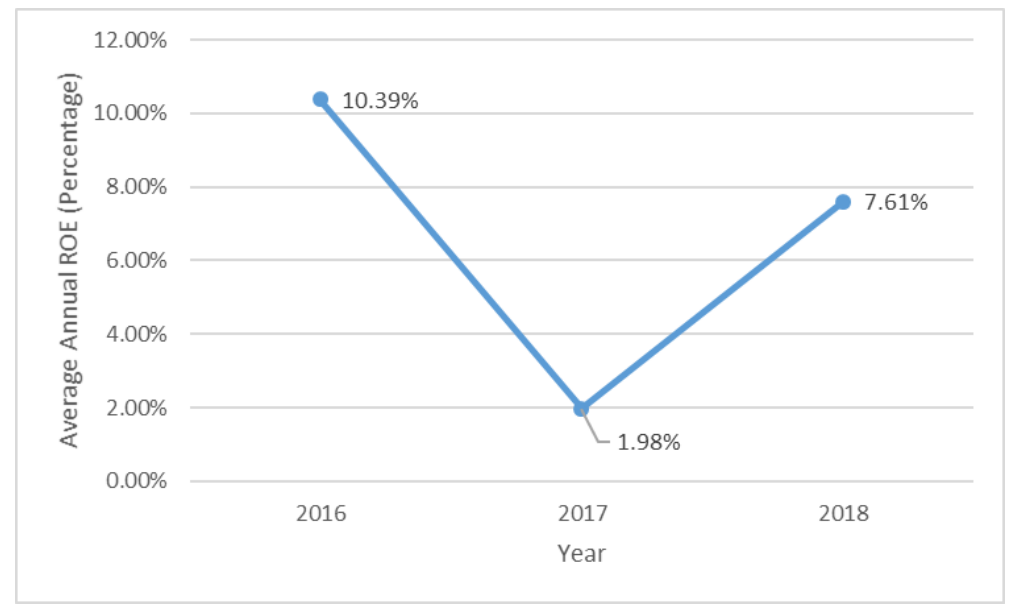

Figure 1. Trends in Financial Performance

The ROE of the commercial banks was captured on a time period spanning 3 years between the year 2016, 2017 and 2018. The trends of financial performance were established as indicated on figure 1. These trends were established based on mean annual ROE for all the commercial banks. Accordingly, in the year ended $31^{\text {st }}$ December 2016 average ROE ( $M=10.39)$, in year ended $31^{\text {st }}$ December year 2017 average ROE $(M=1.98)$ and in year ended $31^{\text {st }}$ December 2018 average R0E ended $31^{\text {st }}$ December $(M=7.61)(C B K, 2016-2018)$. Figure 1 shows the unstable average figures of ROE in the Kenyan commercial banks, which is not a favourable condition in a growing economy. A stable and higher return on equity portrays company's effectives, hence the attractiveness to investors who are source of company's sustainability. As noted, this study was necessary and serves as a wake-up call to bankers in Kenya to enhance strategies that can accelerate the country's economy and achieve a global business competitive strength. Moreover, investors use ROE to assess the market value and growth of banks because of the insurance incentive by the government. This also is a benefit to banks since ROE is earned from the investor's capital which banks should maintain in order to grow earning as they maximize shareholders value (Pennacchi \& Santos, 2018).

To establish the effect of strategic intelligence on performance of Commercial banks in Kenya, multivariate regression models were used. Two regression models, for NFP and ROE were established as shown:

$$
\begin{aligned}
& \mathrm{NFP}=\beta_{0}+\beta_{1} \mathrm{BI}+\beta_{2} \mathrm{CI}{ }_{+} \beta_{3} \mathrm{KM}_{+} \varepsilon \\
& \mathrm{ROE}=\beta_{0}+\beta_{1} \mathrm{BI}+\beta_{2} \mathrm{CI}_{+} \beta_{3} \mathrm{KM}_{+} \varepsilon
\end{aligned}
$$


The model summary that reveals the coefficients of determination is presented in Table 2 .

Table 2. Model Summary

\begin{tabular}{lllll}
\hline Model & R & R Square & Adjusted R Square & Std. Error of the Estimate \\
\hline NFP & 0.935 & 0.874 & 0.871 & 0.47551 \\
ROE & 0.876 & 0.767 & 0.762 & 9.140842 \\
& Predictors: (Constant), Knowledge & Management, Competitive Intelligence, Business Intelligence \\
\hline
\end{tabular}

The results in table 2 show an adjusted R-square value of 0.871 for the regression model linking non-financial performance with strategic intelligence, which indicates that there was no overestimation of the model. This means that up to $87.1 \%$ of variation in non-financial performance of the commercial banks in Kenya can be explained by the three measures of strategic intelligence.

The results also showed an adjusted R-square value of 0.762 for the regression model linking ROE with strategic intelligence, which indicates that there was no overestimation of the model as well. This implies that up to $76.2 \%$ of variation in ROE of the commercial banks in Kenya can be explained by the three measures of strategic intelligence. These findings are consistent with that of a study by Richards, Yeoh, Chong and Popovic (2017) which established that the more the effectiveness of a business intelligence implementation in a firm, the more effective the planning and analytic practices become. The study also demonstrated that business intelligence effectiveness is strongly related to business administration, planning and to measurements of performance. The findings for the ANOVA (Model fitness) are presented in Table 3.

Table 3. ANOVA Results

\begin{tabular}{|c|c|c|c|c|c|c|}
\hline Model & & $\begin{array}{l}\text { Sum } \\
\text { Squares } \\
\end{array}$ & Df & Mean Square & $\mathbf{F}$ & Sig. \\
\hline \multirow[t]{3}{*}{ NFP } & Regression & 213.399 & 3 & 71.133 & 314.602 & .000 \\
\hline & Residual & 30.75 & 136 & 0.226 & & \\
\hline & Total & 244.15 & 139 & & & \\
\hline \multirow[t]{3}{*}{ ROE } & Regression & 37337.22 & 3 & 12445.74 & 148.953 & .000 \\
\hline & Residual & 11363.48 & 136 & 83.555 & & \\
\hline & Total & 48700.69 & 139 & & & \\
\hline
\end{tabular}

The results in Table 3 on the Analysis of Variance indicate that for the regression model linking non-financial performance with strategic intelligence, the $\mathrm{F}$ statistic value of 314.602 was significant at $5 \%$ level of significance $(\mathrm{Sig}=0.000)$. These findings imply that the model linking non-financial performance with strategic intelligence (knowledge management, competitive intelligence, business intelligence) was of good fit and that strategic intelligence contribute significantly to changes in non-financial performance of commercial banks in Kenya. The results of this study are in line with Lorenzetti (2010) in Italian firms. It was also established in Table 3, for the regression model linking financial performance with strategic intelligence, the F statistic value of 148.953 was also significant at $5 \%$ level of significance $(\mathrm{Sig}=0.000)$. The findings for model coefficients are presented in Table 4.

Table 4. Regression Model Coefficients

\begin{tabular}{lllllll}
\hline Model & & \multicolumn{2}{c}{ Unstandardized Coefficients } & \multicolumn{3}{c}{ Standardized Coefficients } \\
\hline \multirow{3}{*}{ NFP } & (Constant) & B & Std. Error & Beta & t & Sig. \\
& Business Intelligence & -4.055 & 0.281 & & -14.423 & 0.000 \\
& Competitive Intelligence & 0.612 & 0.168 & 0.264 & 3.647 & 0.000 \\
& Knowledge Management & 1.206 & 0.131 & 0.597 & 9.215 & 0.000 \\
\multirow{2}{*}{ ROE } & (Constant) & -83.592 & 0.091 & 0.115 & 2.017 & 0.046 \\
& Business Intelligence & 8.141 & 3.405 & & -15.466 & 0.000 \\
& Competitive Intelligence & 5.812 & 2.516 & 0.248 & 2.524 & 0.013 \\
& Knowledge Management & 10.666 & 1.749 & 0.204 & 2.310 & 0.022 \\
& & & & 0.474 & 6.099 & 0.000 \\
\hline
\end{tabular}


Finding in table 4 implies that the model linking financial performance with strategic intelligence was good and fit. In essences, modelling is essential in business setting since it highlights areas that teams or systems need to work on to achieve the organisations' goals and objectives. Models envisions systems in multiple perspectives, hence enabling discovery of causes and effects, reducing systems defects, and finally exploring alternatives. This also helps to improved impacts and possible consequences in case of laxity. From table 4 therefore, the results show that strategic intelligence contributes significantly to changes in financial performance of commercial banks in Kenya. Thus, the implementation of strategic intelligence in commercial banks in Kenya may stimulate systems' power to implement needed change for economic growth. This argument is in line with Levine, Bernard, \& Nagel (2017), accordingly, the scholars associates strategic intelligence with cognitive capability to anticipate competitor's behaviour.

\section{Conclusion and Policy Recommendation}

\subsection{Conclusion}

This study investigated the effect of strategic intelligence on the performance of commercial banks in Kenya. The specific objective was to determine the role of strategic intelligence in the context of commercial banks in Kenya. Findings indicate therefore, that strategic intelligence has a statistically significance on the performance of commercial banks in Kenya. Moreover, both financial and non-financial measures of performance are relevant in the banking sector and growth of Kenyan economy. Further, the power found in strategic intelligence is both valuable, rare, inimitable, and non-substitutable, but also dynamic capable for growth, sustainability, and superior performance of the banking industry in Kenya.

\subsection{Policy Implications}

Based on the study findings, a set of policy options are recommended for improving performance of commercial banks in Kenya. The study established that strategic intelligence significantly improves performance of commercial banks in Kenya. However, since commercial banks cannot eliminate or prevent uncertainties in a competitive business environment, the study recommends that the corporate level managers of the commercial banks should engage more on improving and development of new business models. Moreover, the commercial banks need better functional forecasting methodologies, training, constructive application of both theories and practice and innovative scientific approaches for testing their strategic intelligence in the market. This implies that commercial bank in Kenya must integrate their training focus and strategy implementation with the intervening variables, focusing on investors interests and other score cards such as Kaplan's balanced score card.

\subsection{Limitation and Future Research}

This study sought to investigate the role of strategic intelligence in the context of commercial banks in Kenya. The researcher administered both open and closed ended questionnaires, and an online document review, which provide independent responses and specific data for Kenya commercial banks' ROE for years; 2016, 2017 and 2018, which were regarded as accurate to the expectation of the researcher. Moreover, the researcher conducted a cross-sectional data collection procedure, which was important for current required data. Strategic intelligence was defined through a synergy of business intelligence, competitive intelligence, and knowledge management, leaving out artificial intelligence. Other studies can be carried out and consider the four components of strategic intelligence and include variables such as system thinking, visioning, alliances, foresight, intuition which are part of strategic intelligence soft skills but were not investigated in this study. Since this study was based on banking industry in Kenya, future research can be carried out in different economic sectors to validate these findings.

\section{References}

Abbaspour, A., Amirkhani, A. H., Ezzat, A. A. P., \& Hozori, M. J. (2018). Identifying and describing sub-processes in the strategic intelligence process by qualitative content analysis in an inductive way. Journal of Intelligence Studies in Business, 8(1), 16-24.

Acheson, H. (2008). Strategic Policy Intelligence-setting priorities and evaluating impacts-Ireland. Memeo, Retrieved from www.OECD.org/science/inno/41379672.pdf

Ahmed, F., \& Runggcharoenkitkul, P. (2014). Cambodia's banking sector: Are more banks always better. Cambodia, Entering a New Phase of Growth, Washington, DC: IMF, 51-61.

Almarri, K., \& Gardiner, P. (2014). Application of resource-based view to project management research: supporters and opponents. Procedia-Social and Behavioral Sciences, 119(7), 437-445.

Alnoukari, M., Razouk, R., \& Hanano, A. (2016). BSC-SI, A framework for integrating strategic intelligence in corporate strategic management. International Journal of Strategic Information Technology and 
Applications (IJSITA), 7(1), 32-44.

AlSuwaidan, L., \& Zemirli, N. (2015). Toward a knowledge-based model for real-time business intelligence. In 2015 Science and Information Conference (SAI) (pp. 443-446). IEEE.

Andersén, J. (2011). Strategic resources and firm performance. Management Decision.

Bang, M. (2017). A Shared Epistemological View within Military Intelligence Institutions. International Journal of Intelligence and Counterintelligence, 30(1), 102-116.

Barney, J. B. (2001). Resource-based theories of competitive advantage: A ten-year retrospective on the resource-based view. Journal of management, 27(6), 643-650.

Bititci, U. S. (2016). Managing business performance: The science and the art. John Wiley \& Sons.

Bogićević, J., Domanović, V., \& Krstić, B. (2016). The role of financial and non-financial performance indicators in enterprise sustainability evaluation. Ekonomika, 62(3), 1-13.

Central Bank of Kenya. (2017). Bank Supervision: Annual Report. Nairobi, Kenya.

Cheng, H. G., \& Phillips, M. R. (2014). Secondary analysis of existing data: opportunities and implementation. Shanghai archives of psychiatry, 26(6), 371.

Chironga, M., Cunha, L., \& De Grandis, H. (2018). Roaring to Life: Growth and Innovation in African Retail Banking. McKinsey \& Company.

Das, T. K., \& Teng, B. S. (2000). A resource-based theory of strategic alliances. Journal of management, 26(1), 31-61.

Dhami, M. K., Mandel, D. R., Mellers, B. A., \& Tetlock, P. E. (2015). Improving intelligence analysis with decision science. Perspectives on Psychological Science, 10(6), 753-757.

Ekinci, R., \& Poyraz, G. (2019). The Effect Risk on Financial Performance of Deposit Banks in Turkey, $3^{r d}$ World Conference on Technology, Innovation and Entrepreneurship (WOCTINE)

Eltinay, N. B., \& Masri, R. (2014). Understanding impact of financial and non-financial measurements in Sudanese banks performance. International Journal of Humanities and Management Sciences, 2(3), 98-104.

Essays, U. K. (2018). Limitations of the Resource Based View Management Essay.

Fernández-Villacañas Marín, M. (2015). The global strategic intelligence management. Learning and thinking skills. [Online] University of Alcalá (UAH). Retrieved July 14, 2016, from http://europehome-project.eu/resources/learning-materials

Freeman, R. E., Wicks, A. C., \& Parmar, B. (2004). Stakeholder theory and "the corporate objective revisited". Organization science, 15(3), 364-369.

Fuertes, G., Alfaro, M., Vargas, M., Gutierrez, S., Ternero, R., \& Sabattin, J. (2020). Conceptual Framework for the Strategic Management: A Literature Review-Descriptive. Journal of Engineering, 2020.

Gaudreau, P., \& Braaten, A. (2016). Achievement goals and their underlying goal motivation: Does it matter why sport participants pursue their goals? Psychologica Belgica, 56(3), 244.

Gill, P. (2010). Theories of intelligence. In The oxford handbook of national security intelligence (pp. 43-58). Oxford: Oxford University Press.

Gingrich, P. (2007). Power, domination, legitimation, and authority. Resource document. University of Regina, Department of Sociology and Social Studies.

Gomes, J., \& Romão, M. (2013). How benefits management helps Balanced Scorecard to deal with business dynamic environments. Tourism \& Management Studies, 9(1), 129-138.

Hedin, H., Hirvensalo, I., \& Vaarnas, M. (2011). The handbook of market intelligence: understand, compete and grow in global markets. John Wiley \& Sons.

Heidenrich, J. G. (2007). The Intelligence Community's Neglect of Strategic Intelligence. Studies in Intelligence, 51(2), 15-26.

Johnson, R. B., Onwuegbuzie, A. J., \& Turner, L. A. (2007). Toward a definition of mixed methods research. Journal of mixed methods research, 1(2), 112-133.

Kabajeh, M. A. M., Al Nuaimat, S. M. A., \& Dahmash, F. N. (2012). The relationship between the ROA, ROE and ROI ratios with Jordanian insurance public companies market share prices. International Journal of 
Humanities and Social Science, 2(11), 115-120.

Kaplan, R. S. (2009). Conceptual foundations of the balanced scorecard. Handbooks of management accounting research, 3, 1253-1269.

Kaplan, R. S., \& Norton, D. P. (2005). Creating the office of strategy management. Boston, MA: Division of Research, Harvard Business School.

Khedr, A. E., Abdel-Fattah, M. A., \& Solayman, M. M. (2015). Merging Balanced Scorecards and Business Intelligence Techniques: An Applied case on the IT Subsidiary Company in the Egyptian Civil Aviation. International Journal of Computer Applications, 121(11).

Kijewska, A. (2016). Determinants of the return on equity ratio (ROE) on the example of companies from metallurgy and mining sector in Poland. Metalurgija, 55(2), 285-288.

Kinyua, G. M., Muathe, S. M. A., \&Kilika, J. M. (2015). Effect of knowledge conversion and knowledge application on performance of commercial banks in Kenya. International Journal of Education and Research, 3(10), 431-445.

Koh, E. T., \& Owen, W. L. (2012). Introduction to nutrition and health research. Springer Science \& Business Media.

Kor, Y. Y., \& Mahoney, J. T. (2004). Edith Penrose's (1959) contributions to the resource-based view of strategic management. Journal of management studies, 41(1), 183-191.

Kumaresan, A., \& Liberona, D. (2013). Promoting knowledge sharing and knowledge management in organisations using innovative tools. In 7th International Conference on Knowledge Management in Organizations: Service and Cloud Computing (pp. 175-184). Springer, Berlin, Heidelberg.

Kuosa, T. (2014). Towards strategic intelligence: foresight, intelligence, and policymaking. Dynamic Futures.

Levine, S. S., Bernard, M., \& Nagel, R. (2017). Strategic intelligence: The cognitive capability to anticipate competitor behavior. Strategic Management Journal, 38(12), 2390-2423.

Liebowitz, J. (2006). Strategic intelligence: business intelligence, competitive intelligence, and knowledge management. CRC Press.

Lucianetti, L., Battista, V., \& Koufteros, X. (2019). Comprehensive performancemeasurement systems design and organizational effectiveness. International Journal of Operations \& Production Management, 39(2), 326-356.

Malgwi, A. A., \& Dahiru, H. (2014). Balanced Scorecard financial measurement of organizational performance: A review. IOSR Journal of Economics and Finance, 4(6), 1-10.

Mandel, D. R., \& Barnes, A. (2014). Accuracy of forecasts in strategic intelligence. Proceedings of the National Academy of Sciences, 111(30), 10984-10989.

Masharsky, A. (2014). Tendencies and Factors of Regulation of Development in Latvian Banking System. Regional Formation and Development Studies, 11(3), 155-164.

Mashovic, A. (2018). Key financial and nonfinancial measures for performance evaluation of foreign subsidiaries. Journal of Contemporary Economic and Business Issues, 5(2), 63-74.

McFarlane, D. A. (2011). Personal knowledge management (PKM): are we ready? Journal of Knowledge Management Practice, 12(3), 108-114.

Meldrum, M., \& McDonald, M. (1995). The Ansoff Matrix. In Key Marketing Concepts (pp. 121-126). Palgrave, London.

Mittal, V., \& Frennea, C. (2010). Customer satisfaction: a strategic review and guidelines for managers. MSI Fast Forward Series, Marketing Science Institute, Cambridge, MA.

Momanyi, D. K. (2018). Influence of Financial Regulation in Kenya on Financial Inclusion: A Case Study of the Banking Industry in, KBA Centre for Research on Financial Markets and Policy® Working Paper Series.

Morse, J. M., \& Niehaus, L. (2009). Mixed methods design: Principles and procedures-Volume 4, developing qualitative inquiry. Philadephia, PA: Pennsylvania State University.

Morton, K. (2016). Exploring bank managers' strategies for developing millennials for leadership roles in commercial banks.

Moussu, C., \& Petit-Romec, A. (2017). ROE in banks: Performance or risk measure? Evidence from financial 
crises. Finance, 38(2), 95-133.

Mugo, H. W., Wanjau, K., \& Ayodo, E. (2012). An investigation into competitive intelligence practices and their effect on profitability of firms in the banking industry: A case of Equity Bank.

Musau, S., Muathe, S., \& Mwangi, L. (2018). Financial inclusion, bank competitiveness and credit risk of commercial banks in Kenya. International Journal of Financial Research, 9(1), 203.

Mutuku, M. K., Muathe, S., \& James, R. (2019). Mediating Effect of Competitive Advantage on the Relationship Between E-commerce Capability and Performance: Empirical Evidence from Commercial Banks in Kenya. European Journal of Business and Management, 11(17), 48-57.

Mwenzwa, E. M., \& Misati, J. A. (2014). Kenya's Social Development Proposals and Challenges: Review of Kenya Vision 2030 First Medium-Term Plan, 2008-2012.

Namada, J. M. (2018). Organizational learning and competitive advantage. In Handbook of Research on Knowledge Management for Contemporary Business Environments (pp. 86-104). IGI Global.

Nason, R. S., \& Wiklund, J. (2018). An assessment of resource-based theorizing on firm growth and suggestions for the future. Journal of Management, 44(1), 32-60.

Neely, A., Mills, J., Platts, K., Richards, H., Gregory, M., Bourne, M., \& Kennerley, M. (2000). Performance measurement system design: developing and testing a process-based approach. International journal of operations \& productionmanagement, 20(10), 1119-1145.

Nenadal, J. (2016). Adequacy, suitability, effectiveness, and efficiency of quality management systems: how to perceive and assess them? Quality Innovation Prosperity, 20(2), 39-52.

Norman, D. (2017). Returns on Equity, Cost of Equity, and the Implications for Banks. RBA Bulletin, March 51-58.

OConnell, V., \& OSullivan, D. (2016). Are nonfinancial metrics good leading indicators of future financial performance? MIT Sloan Management Review, 57(4), 21.

Odhiambo, M. O. (2013). Releasing our full potential: The ASAL policy, its promise and challenges. A briefing note for members of county assemblies, representatives, leaders, CSO and ASAL stakeholders.

OECD (2015). Building more effective, accountable, and inclusive institutions for all. Element 6, PAPER 1.

Olsen, E. (2011). Strategic planning for dummies. John Wiley \& Sons.

Pennacchi, G., \& Santos, J. A. (2018). Why do banks target ROE? FRB of New York Staff Report, 855.

Pitelis, C. N. (2004). Edith Penrose and the resource-based view of (international) business strategy. International business review, 13(4), 523-532.

Poteat S. E. (2011). The Evolution of the Intelligence Process at the U.S. Central Intelligence Agency. UK Vision 2 Paper.

Richards, G., Yeoh, W., Chong, A. Y. L., \& Popovič, A. (2017). Business intelligence effectiveness and corporate performance management: An empirical analysis. Journal of Computer Information Systems, 1-9.

Schmidt, J. M. (2015). Intelligence, Strategic Warning, and Foresight: Completing the Package for Decision-Makers. Journal of Intelligence \& Analysis, 22(2), 11-30.

Seawright, J. (2016). Multi-method social science: Combining qualitative and quantitative tools. Cambridge University Press.

Sihag, V., \& Rijsdijk, S. A. (2019). Organizational controls and performance outcomes: A meta-analytic assessment and extension. Journal of Management Studies, 56(1), 91-133.

Silas, N. (2013). Strategic intelligence role in the management of organizations. The USV annals of economics and public administration, 2(18), 109-116.

Striteska, M., \& Spickova, M. (2012). Review and comparison of performance measurement systems. Journal of Organizational Management Studies, 1 .

Svensson, A. B. G., Pellissier, R., \& Kruger, J. P. (2011). A study of strategic intelligence as a strategic management tool in the long-term insurance industry in South Africa. European Business Review.

Team, T., Perrault, M. F., Kilo, O. M. M., \& Hettinger, L. M. P. (2013). African Development Bank Group. Kenya Bank Group. 
Teece, D. J., Pisano, G., \& Shuen, A. (1997). Dynamic capabilities and strategic management. Strategic management journal, 18(7), 509-533.

Timothy, V. (2010). A Review of Approaches of Resource-Based Empirical Research in Banking. International Journal of Economic Finance, 4.

Treverton, G. F., Jones, S. G., Boraz, S., \& Lipscy, P. (2006). Toward A Theory Of Intelligence. Workshop Report. Rand Corp Arlington VA National Security Research Div.

Turner, J. C. (2005). Explaining the nature of power: A three-process theory. European journal of social psychology, 35(1), 1-22.

Twum Amoako, B. (2014). The importance of Business Intelligence as a decision-making tool: case study electricity company of Ghana (ECG).

United Nations. Economic Commission for Europe. Committee on Environmental Policy. (2008). ECE/CEP/142. United Nations Publications.

Van Looy, A., \& Shafagatova, A. (2016). Business process performance measurement: a structured literature review of indicators, measures and metrics. Springer Plus, 5(1), 1797.

Waheed, A., Abbas, Q., \& Malik, O. F. (2018). 'Perceptions of performance appraisal quality 'and employee innovative behavior: do psychological empowerment and 'perceptions of HRM system strength 'matter? Behavioral Sciences, 8(12), 114.

Westerfield, H. B. (2001). Strategic Intelligence, International Encyclopedia of the Social \& Behavioural Sciences.

Wilensky, H. L. (2015). Organizational intelligence: Knowledge and policy in government and industry (Vol. 19). Quid Pro Books.

Xu, M., \& Kaye, R. (2007). The nature of strategic intelligence, current practice and solutions. In Managing Strategic Intelligence: Techniques and Technologies (pp. 36-54). IGI Global.

Zimmermann, S. (2019). Same, Same but Different: How and Why Banks Approach Sustainability. Sustainability, 11(8), 2267.

\section{Copyrights}

Copyright for this article is retained by the author(s), with first publication rights granted to the journal.

This is an open-access article distributed under the terms and conditions of the Creative Commons Attribution license (http://creativecommons.org/licenses/by/4.0/). 